\title{
THE ECONOMETRIC THEORY AWARDS 2020
}

I am delighted to announce the following Econometric Theory Awards for 2020 .

Multa Scripsit (2020): Anders Bredahl Kock

Bent Nielsen

Plura Scripsit (2020): Hidalgo Javier

There are presently three levels of the ET award: Multa Scripsit, Plura Scripsit, and Plurima Scripsit. The awards are made annually using an automated point system based on an author's cumulative publications in ET. A description of the award system and a copy of the ET Award Certificate may be viewed on the ET website at https://www.cambridge.org/core/journals/econometrictheory/et-awards.

Cambridge University Press joins me in congratulating the recipients of the 2020 ET Awards and thanking them for their sustained contributions to econometric theory.

Peter C. B. Phillips

January 2020 